\title{
Pengaruh Penerapan Sistem Administrasi Perpajakan Modern, Kualitas Pemeriksaan Pajak Dan Kesadaran Masyarakat Terhadap Kepatuhan Wajib Pajak Orang Pribadi Yang Memiliki UMKM di Kota Jayapura
}

\author{
Megezz Yizhart Duwiri ${ }^{1}$ \\ megezzduwiri11@gmail.com \\ Theo Allo Layuk ${ }^{1}$ \\ Novalia H. Bleskadit ${ }^{1}$ \\ Jurusan Akuntansi, Fakultas Ekonomi dan Bisnis Universitas Cenderawasih
}

\begin{abstract}
The purpose of this study was to determine the effect of the adoption of the Modern Tax Administration System, the Quality of Tax Examination, and Public Awareness of the Taxpayer Compliance of Individuals Who Own SMEs in Jayapura City.

Data collection techniques used in this study were questionnaires (questionnaire) with respondents as many as 100 WPOP who have MSMEs in city of Jayapura. Data analysis in this study carried out quantitatively, using multiple linear regression statistical tools (Multiple Linear Regression) with the help of SPSS 16 statistical software.

The results of this study prove that there is a significant influence between the Variables in the Implementation of Modern Tax Administration Systems and the Quality of Tax Examinations. Meanwhile, the Public Awareness variable does not affect the compliance of taxpayers who have MSMEs in city of Jayapura.
\end{abstract}

Keywords: Application of Modern Tax Administration System; Quality of Tax Examination; Public Awareness of Personal Taxpayer Compliance.

\begin{abstract}
Abstrak
Tujuan penelitian ini untuk mengetahui Pengaruh Penerapan Sistem Administrasi Perpajakan Modern, Kualitas Pemeriksaan Pajak dan Kesadaran Masyarakat terhadap Kepatuhan Wajib Pajak Orang Pribadi Yang Memiliki UMKM di Kota Jayapura.

Teknik pengumpulan data yang digunakan dalam penelitian ini adalah Kuesioner (Angket) dengan responden sebanyak 100 WPOP Yang Memiliki UMKM di Kota Jayapura. Analisis data dalam penelitian ini dilakukan secara kuantitatif, dengan menggunakan alat statistik regresi linier berganda (Multiple Linier Regresion) dengan bantuan software statistik SPSS 16.

Hasil penelitian ini membuktikan bahwa adanya pengaruh yang signifikan antara Variabel Penerapan Sistem Administrasi Perpajakan Modern dan Kualitas Pemeriksaan Pajak. Sedangkan, Variabel Kesadaran Masyarakat tidak berpengaruh terhadap Kepatuhan Wajib Pajak Yang Memiliki UMKM di Kota Jayapura.
\end{abstract}

Kata kunci: Penerapan Sistem Administrasi Perpajakan Modern; Kualitas Pemeriksaan Pajak; Kesadaran Masyarakat terhadap Kepatuhan Wajib Pajak Orang Pribadi

\section{Pendahuluan}

Dalam suatu Negara untuk melaksanakan pemerintahan serta pembangunan, pemerintah memerlukan dana yang tidak sedikit. Negara mempunyai potensi sumber daya untuk memperoleh dana ialah berbentuk hasil kekayaan alam ataupun iuran dari warga masyarakat, salah satu wujud iuran warga masyarakat merupakan pajak. Sejalan dengan perekonomian yang ada sektor pajak memiliki peranan yang sangat besar dalam menghasilkan penerimaan bagi Negara dan sangat diperlukan guna mewujudkan kelangsungan serta peningkatan pembangunan nasional. Penerimaan pajak pula memiliki peranan yang sangat mempengaruhi dalam pos penerimaan dalam negara. Penerimaan pajak berasal dari jumlah iuran masyarakat (yang dipungut berdasarkan undang-undang) yang diterima oleh Negara dalam suatu masa yang nantinya digunakan oleh Negara untuk membayar pengeluaran umum. Masyarakat diwajibkan untuk ikut serta dalam membayar pajak sebagai bentuk peranan untuk 
menjalankan fungsi pemerintahan.

Pemerintah telah empat kali melakukan Reformasi Administrasi Perpajakan, tahun 1983, 1994, 1997, dan 2000. Reformasi ini dilakukan untuk menyesuaikan dengan perkembangan dunia usaha dan kebijakan pemerintah yang dapat dikategorikan sebagai reformasi perpajakan adalah reformasi tahun 1983, di mana terjadi perubahan sistem yang mendasar dari "Official Assessment System" ke "Self Assessment System” (Surjono, 2015). Prinsip self Assessment System adalah sebuah prinsip untuk memenuhi kewajiban perpajakan yang diharuskan oleh para Wajib Pajak (WP) sesuai ketentuan peraturan undang-undang perpajakan dalam hal hitung, bayar dan lapor sendiri pajak yang terutang, sehingga diberikan kepercayaan kepada WP sendiri untuk penentuan besarnya pajak yang terutang melalui dokumen Surat Pemberitahuan (SPT) yang disampaikan baik secara langsung, online, pos, maupun melalui ASP (Suparman, 2018).

Penerapan Good governance yang transparan serta akuntabel, dengan memakai sistem data teknologi yang profesional serta terbaru ialah jiwa dari modernisasi. Diberikan pelayanan prima sekalian pengawasan intensif kepada para WP merupakan bagaikan wujud strategi yang ditempuh (Rahayu, 2010). Pada tahun 2005 DJP menghasilkan beberapan sistem administrasi perpajakan yakni e-Registration, e-Filling, e-SPT, dan e-Billing dengan memanfaatkan teknologi yaitu $e$-System (Electronic System). Modernisasi teknologi ini dipercaya bakal jadi salah satu pilar utama dari reformasi perpajakan karena akan sangat berguna sebagai usaha dalam peningkatan tax ratio, penghindaran dan penggelapan pajak, serta mendorong kepatuhan WP.

Kebijakan pemerintah menetapkan insentif bagi pelaku UMKM dengan merendahkan tarif PPh Final menjadi 0,5 persen dari sebelumnya 1 persen. PP 23/2018 tentang Pajak Penghasilan atas Penghasilan dari Usaha yang Diterima atau Diperoleh Wajib Pajak yang memiliki peredaran bruto tertentu. PP ini merupakan perubahan atas PP 46/2013. Berdasarkan isu yang sudah jelaskan terkait dengan pengurangan tarif PPh Final 0,5 persen dari 1 persen sebelumnya, penulis ingin melihat apakah dengan pengurangan tarif pajak memberikan kesadaran terhadap para WP atau tidak.

Pemeriksaan pajak adalah salah satu usaha atau upaya pemerintah dalam mennggarap kecurangan karena pada masa saat ini banyak sekali terjadi kecurangan-kecurangan yang dilakukan oleh para WP, antara lain ialah memanipulasi pendapatan ataupun penyelewengan dana pajak. Pemeriksaan pajak dimaksudkan untuk menguji sejauhmana kepatuhan WP di dalam memenuhi kewajiban perpajakannya (Cermati.com, 2019). Dengan adanya self assasment system, maka Wajib Pajak menghitung, membayar, dan melaporkan sendiri besaran pajaknya di Kantor Pelayanan Pajak, sehingga menuntut DJP agar selalu melaksanakan pembinaan dan pengawasan dalam perpajakan terhadap Wajib Pajak. Salah satu wujud pengawasan yang dilakukan DJP adalah melalui pemeriksaan pajak.

Kepatuhan pajak merupakan salah satu hal yang harus dipenuhi untuk menjamin pelaksanaan pemerintah sesuai dengan prinsip-prinsip tata kelola Negara yang baik. Ketaatan harus dilaksanakan oleh semua pihak untuk menjamin rasa keadilan bagi seluruh pihak. Jika masyarakat dituntut untuk membayar pajak namun di sisi lain Negara tidak dapat memenuhi kewajiban untuk memakmurkan masyarakat maka sudah dapat dipastikan partisipasi masyarakat untuk membayar pajak akan rendah.

Jayapura, Jubi - Dalam rangka mendorong penigkatan kepatuhan (WP) di wilayah Papua, Kantor Wilayah DJP Papua dan Maluku mengelar kegiatan pekan panutan pajak di Kanwil DJP Papua dan Maluku, Kamis (27/2/2020). Kepala Kanwil DJP Papua dan Maluku, Arridel Mindra, berkata dalam kegiatan tersebut pihaknya menghadirkan para pejabat besar di Papua, untuk ikut serta dalam pelaporan SPT Tahunan melalui aplikasi e- Filing.

Dikatakan Arridel, jumlah WP yang terdftar di Kanwil DJP Papua dan Maluku sebanyak 850. 428, dengan jumlah WP yang harus lapor SPT sebanyak 373. 091.“ WP yang lapor pada tahun 2019 sebanyak 252. 282 (87\%). Diharapkan pekan panutan pajak mengaitkan pejabat besar di Papua untuk menekan kenaikan angka kepatuhan WP di daerah Papua dan sekitarnya pada tahun 2020," ucap Arridel. Dia menambahkan Wajib Pajak yang terdaftar di Kanwil DJP Papua dan Maluku yakni terdiri dari Wajib Pajak Badan, Perorangan Non Karyawan, Perorangan Karyawan dimana yang sudah melaporkan kewajiban perpajakannya dari tujuh Kantor Pelayanan Pajak (KPP yakni Ambon, Sorong, Jayapura, Timika, Biak, Manokwari, Merauke, yang dilansir oleh jubi.co.id (Kristianto Galuwo, 2020) 
Penelitian ini adalah replikasi dari penelitian sebelumnya yang membuktikan terdapat pengaruh positif yang kuat antara penerapan sistem administrasi perpajakan modern, kualitas pemeriksaan dan kesadaran terhadap kepatuhan WPOP di KPP Pratama Bandung Cibeunying (Lumbantoruan, 2014). Namun dengan perbedaan lokasi penelitian, sampel penelitian dan model kerangka pemikiran penelitian.

\section{Tinjauan Pustaka}

\subsection{Teori Behavior}

Theory of planned behavior merupakan pengembangan dari theory of reasoned action yang dibuat karena keterbatasan model asli dalam menghadapi perilaku dimana orang memiliki kontrol perilaku yang tidak lengkap (Ajzen, 1991). Perilaku seseorang dapat dipengaruhi oleh niat yang dimiliki, sedangkan niat seseorang dibentuk berdasarkan faktor-faktor berikut (Ajzen (1991) dalam (Valenty, Yola Andesta, 2019):

\section{Behavioral Belief}

Behavioral belief adalah keyakinan kepada hasil dari suatu perilaku yang membentuk sikap, dimana keyakinan dari individu terhadap hasil dari suatu perilaku dan evaluasi atas hasil tersebut.

2. Normative Belief

Normative belief merupakan keyakinan tentang harapan normatif orang lain dan motivasi untuk memenuhi harapan tersebut.

3. Control Belief

Control belief adalah kepercayaan mengenai keberadaan factor-factor yang akan memfasilitasi atau mengalangi kinerja dari perilaku.

\subsection{Teori Persepsi}

Pada hakikatnya persepsi meliputi proses yang dilakukn seseorang dalam memahami informasi dan proses pemahamn melalui penglihatan, pendengaran dan perasan. Dengan demikian persepsi ialah proses seorang dalam membagikan kesan, evaluasi, komentar, menguasai, mengorganisasi, menafsirkan yang membolehkan suasana, kejadian yang membagikan kesan sikap yang positif ataupun negatif dengan menyadari tentang apa yang diterima lewat inderanya, berarti seorang hendak menginterpretasikan serta memperhitungkan sesuatu objek yang hendak tercemin dari reaksi yang mencuat yang bisa berbentuk asumsi ataupun sikap (Dewi, 2011).

Dengan demikian persepsi adalah proses untuk memahami dan kemudian menafsirkan suatu obyek tertentu, di mana penafsiran itu dipengaruhi oleh nilai- nilai yang ada dalam individu tersebut. Pesepsi seseorang sangat dipengaruhi oleh bermacam-macam faktor diantaranya yaitu lingkungan sosial, di mana seseorang yang bersangkutan melakukan interaksi sosial (Plano, 2005). Lingkungan sosial akan membentuk kepribadian, cara pandang seseorang terhadap suatu obyek dan cara berpikir. Persepsi individu akan membentuk persepsi masyarakat, mengingat bahwa masyarakat merupakan kumpulan individu yang saling mengadakan interaksi sosial.

\subsection{Sistem Administrasi Perpajakan Modern}

Menurut Ensiklopedi perpajakan bahwa administrasi perpajakan (tax administration) adalah langkah-langkah atau cara pemungutan pajak yang dingungkapkan oleh Sophar Lumbantoruan. Peran dari administrasi perpajakan yang dikemukakan oleh Liberty Pandiangan bahwa untuk merealisasi peraturan perpajakan serta penerimaan negara yang merupakan amanat APBN maka peran administrasi perpajakan sangatlah penting.

Menurut A. Dunsire, yang mengemukakan kembali oleh Siti Kurnia Rahayu, administrasi berarti: "Sebagai petunjuk, pemerintahan, kegiatan, pelaksanaan, menunjukan, penciptaan prinsipprinsip penerapan kebijakan, melaksanakan kegiatan analisis, menyeimbangkan dan mengemukakan keputusan, pendapat-pendapat kebijakan, sebagai pekerjaan seseorang dan tim dalam mengadakan barang dan jasa publik, serta sebagai arena bidang kerja akademik dan teoritis". (Rahayu, 2009) 


\subsection{Pengertian Kualitas Pemeriksaan Pajak}

Menurut (Mardiasmo, 2009) menjelaskan tentang Pemeriksaan Pajak yaitu: "Pemeriksaan adalah serangkaiaan kegiatan untuk mencari data, mengumpulkan, mengelola serta informasi lainnya untuk menguji kepatuhan pemenuhan kewajiban perpajakan dan sabagai bentuk tujuan lain dalam menjalankan ketentuan peraturan undang-undang perpajakan".

Sedangkan definisi pemeriksaan dijelaskan pada Peraturan Menteri Keuangan tentang Tata Cara Pemeriksaan Pajak Pasal 1 ayat (2) yang berbunyi;

"Pemeriksaan adalah serangkaiaan kegiatan menghimpun dan mengelolah bahan, keterangan, daya/bukti yang dilakukan secara obyektf dan profesional menurut sebuah ukuran pemeriksaan untuk memeriksa kepatuhan dalam memenuhi kewajiban perpajakan serta untuk maksud lain dalam skema menjalankan ketentuan peraturan undang-undang perpajakan”. (Ii, 2013)

\subsection{Pengertian Kesadaran}

Kesadaran WP ialah suatu keadaan dimana para WP memahami, mengetahui serta melakukan ketentuan perpajakannya secara benar dan sukarela. Semakin luas tingkat kesadaran para WP maka semakin baik pengertian/pemahaman serta pelaksanaan kewajiban perpajakan sehingga dapat menaikan tingkat kepatuhan WP. (Muliari dan Setiawan, 2010).

\subsection{Pengertian Kepatuhan Wajib Pajak}

Menurut (Chaizi, 2010) mengatakan bahwa kepatuhan Wajib Pajak dapat didefinisikan dari: "Kepatuhan wajib pajak dalam hal mendaftarkan diri, melaporkan SPT, menghitung dan membayar pajak terutang serta pembayaran tunggakan."

Sedangkan definisi kepatuhan perpajakan menurut Keputusan MenKeu No. 544/KMK.04/2000 yang dikutip oleh Sony Devano dan Siti Kurnia Rahayu (2006 : 112), menjelaskan bahwa:

"Kepatuhan perpajakan merupakan suatu kondisi yang mana tindakan yang dilakukan WP dalam memenuhi kewajiban pajaknya sesuai dengan ketentuan perundang-undangan dan pelaksanaan perpajakan yang berlaku dalam suatu pemerintahan."

\subsection{Penelitian Terdahulu dan Pengembangan Hipotesis}

\subsubsection{Pengaruh Penerapan Sistem Administrasi Perpajakan Modern Terhadap Kepatuhan Wajib Pajak}

Konsep dari moderenisasi perpajakan, ialah pelayanan prima serta pengawasan intensif dengan penerapan good governance. Tingkatkan kepatuhan wajib pajak, keyakinan terhadap administrasi perpajakan dan memacu produktivitas pegawai pajak yang besar merupakan tujuan dari modernisasi. Modernisasi dibagi jadi 3 perihal, ialah reformasi kebijakan, administrasi serta pengawasan. Keberhasilan modernisasi perpajakan itu sendiri membutuhkan kerja sama serta keterbukaan antara pihak DJP maupun Wajib Pajak. Program modernisasi administrasi perpajakan sudah mendapat peran cukup bernilai/penting dalam menetapkan masa depan DJP. Dalam pelaksanaannya, DJP terus berupaya melakukan bermacam-macam proses, yaitu pembenahan organisasi yang kini lebih menyesuaikan pada kebutuhan Wajib Pajak.

Dengan adanya perubahan sistem administrasi perpajakan diharapkan akan mendorong kepatuhan wajib pajak. Dengan kata lain yang dikemukakan dalam penelitian ini adalah penerapan sistem administrasi perpajakan moderen berpengaruh terhadap peningkatn kepatuhan wajib pajak.

Dengan demikian maka diturunkan sebuah hipotesis bahwa:

H1: Penerapan Sistem Administrasi Perpajakan Modern Berpengaruh Terhadap Kepatuhan Wajib Pajak Orang Pribadi 


\subsubsection{Pengaruh Kualitas Pemeriksaan Pajak Terhadap Kepatuhan Wajib Pajak Orang Pribadi}

Pemeriksaan pajak adalah suatu keniscayaan yang harus diterima oleh Wajib Pajak sebagai penyeimbangan dari pelaksanaan sistem perpajakan yang menganut self assessment. Tujuan utama yang ingin dicapai dari pemerikasaan pajak adalah untuk menguji kepatuhan WP.

Dalam penjelasan tersebut diatas, penulis menyimpulakan bahwa pemeriksaan pajak selain bertujuan untuk menguji kepatuhan pemenuhan kewajiban perpajakan. Pemeriksaan pajak juga sekaligus sebagai sarana pembinaan dan pengawasan terhadap Wajib Pajak sehingga dapat tercapai tingkat kepatuhan wajib pajak, terutama dalam pemenuhan kepatuhan ketepatan waktu dalam penyampaian SPT. Dengan dilakukan pemeriksaan, akan diperoleh tingkat kebenaran laporan Wajib Pajak yang dituangkan dalam SPT. Dari hasil pemeriksaan yang telah dilakukan, akan dapat diukur tingkat kepatuhan atau ketaatan Wajib Pajak dalam memenuhi kewajiban perpajakan, sehingga dapat dirumuskan hipotesis sebagai berikut:

H2: Kualitas Pemeriksaan Pajak Berpengaruh Terhadap Kepatuhan Wajib Pajak Orang Pribadi

\subsubsection{Pengaruh Kesadaran Wajib Pajak Terhadap Kepatuhan Pajak Orang Pribadi}

Kesadaran Masyarakat (WP) yaitu suatu keadaan dimana masyarakat mengetahui, memahami dan melaksanakan ketentuan perpajakan dengan baik dan sukarela. Semakin baik tingkat kesadaran masyarakat maka pamahaman dan pelaksanaan kewajiban perpajakan akan baikpula sehingga dapat meningkatkan kepatuhan perpajakan (Muliari dan Setiawan, 2010).

Disampaikan pula oleh Suyatmin (2004:34) dalam penelitiannya juga telah membuktikan bahwa semakin baik kesadaran perpajakan wajib pajak maka semakin baik pula tingkat kepatuhan WP. Dengan demikian maka diturunkan sebuah hipotesis bahwa:

H3: Kesadaran Masyarakat Berpengaruh Terhadap Kepatuhan Wajib Pajak Orang Pribadi

\section{Metode Penelitian}

\subsection{Jenis dan Lokasi Penelitian}

Jenis penelitian ini adalah bersifat kausalitas (sebab-akibat). Penelitian kausalitas bertujuan mengetahui seberapa besar pengaruh variabel independen terhadap variabel dependen. Dimana dalam penelitian ini dimaksud untuk melihat apakah Penerapan Sistem Administrasi Perpajakan Modern, Kualitas Pemeriksaan Pajak dan Kesadaran Masyarakat mempengaruhi Kepatuhan Wajib Pajak Orang Pribadi yang memiliki Usaha Mikro Kecil dan Menengah (UMKM) yang berlokasi di Kota Jayapura. Dengan menyebarkan 100 kuesioner secara online karena kita tahu bahwa saat ini seluruh dunia sedang mengalami kegentaran yang dahsyat oleh karena wabah pandemi virus corona termasuk Negara kita Indonesia dan bahkan wabah tersebut sudah memasuki wilayah Provinsi Papua khususnya Kota Jayapura sehingga dengan akibatnya pandemi virus corona yang mengharuskan Penulis menggunakan strategi penyebaran kuesioner secara online.

\subsection{Populasi dan Sampel}

Populasi adalah wilayah generalsasi yang terdiri atas objek/subjek yang memiliki kualitas dan karakterstik tertentu yang ditetapkn oleh penulis untuk dipelajari dan kemudan ditariik kesimpulan (Sugiyono, 2014). Populasi dalam penelitian ini adalah semua Wajib Pajak Orang Pribadi Yang Memiliki UMKM yang terdaftar di Kantor Pelayanan Pajak Pratama Jayapura.

Sampel adalah bagian dari jumlah dan karakteristik yang dimiliki oleh populasi tersebut (Sugiyono, 2014). Sampel dalam penelitian ini adalah Wajib Pajak Orang Pribadi (WPOP) yang memiliki UMKM sebanyak 100 orang di Kota Jayapura.

\subsection{Jenis dan Sumber Data}

Jenis data dalam penelitian menggunakan data kuantitatif, karena data yang diperoleh nantinya berupa angka atau data kuantitatif yang di angkakan. Dari angka yang diperoleh akan dianalisa lebih lanjut dalam analisa data. Sumber data adalah segala sesuatu yang dapat memberikan informasi mengenai data berdasarkan sumbernya, maka dalam penelitian ini data yang diperoleh menggunakan data primer, yaitu data yang didapat langsung dari responden dengan menyebarkan kuesioner. 


\subsection{Teknik Pengumpulan Data}

Data merupakan faktor penting dalam penelitian, untuk diperlukan teknik tertentu dalam pengumpulan data. Teknik pengumpulan data yang penulis gunakan dalam penelitiian ini adalah kuesioner (Angket). Kuesioner merupakan teknik pengumpuln data yang dilakukan dengan memberikan seperangkat pertanyaan tertulis kepada responden untuk dijawabnya, dapat diberikan secara langsung.

Kuesioner ini ditujukan kepada responden yang berada di Kota Jayapura untuk mengetahui persepsi responden tentang Pengaruh Penerapan Sistem Administrasi Perpajakan Modern, Kualitas Pemeriksaan Pajak dan Kesadaran Masyarakat terhadap Kepatuhan Wajib Pajak Orang Pribadi (WPOP).

\subsection{Variabel Penelitian dan Definisi Operasional}

\section{$\underline{\text { Variabel Dependen (Y) }}$}

\section{Kepatuhan Wajib Pajak Orang Pribadi}

Kepatuhan adalah suatu keadaan dimana wajib pajak memenuhi kewajiban sesuai dengan ketentuan dalam Undang-Undang Perpajakn. (Rahayu, 2010).

Variabel Independen (X)

\section{Penerapan Sistem Administrasi Perpajakan Modern (X1)}

Adminstrasi perpajakan (Tax Administration) ialah cara-cara atau procedur pengenaan dan pemungutaan pajak. Mengenai peran adminstrasi perpajakan, Sofar Lumbantoruan (1997).

\section{Kualitas Pemeriksaan Pajak (X2)}

Pemeriksaan adalah serangkaiaan kegiatan menghimpun dan mengelolah data, keterangan, daya/bukti yang dilaksanakan secara obyektif dan professional menurut sebuah ukuran pemeriksaan untuk memeriksa kepatuhan dalam memenuhi kewajiban perpajakan serta untuk maksud lain dalam skema menjalankan ketentuan peraturan undang-undang perpajakan Peraturan Menteri Keuangan tentang Tata Cara Pemeriksaan Pajak Pasal 1 ayat (2).

\section{Kesadaran Masyarakat (X3)}

Kesadaran WP ialah suatu keadaan dimana para WP memahami, mengetahui serta melakukan ketentuan perpajakannya secara benar dan sukarela. Semakin luas tingkat kesadaran para WP maka semakin baik pengertian/pemahaman serta pelaksanaan kewajiban perpajakan sehingga dapat menaikan tingkat kepatuhan WP. (Muliari dan Setiawan, 2010)

\subsection{Metode Analisis Data}

Analisis data adalah proses penyederhanaan data ke dalam bentuk yang lebih dapat diinterprestasikan. Data yang dihimpun dari hasil penelitian di lapangan, akan penulis bandingkan dengan data kepustakaan, kemudian dilakukan analisis untuk menarik kesimpulan. Analisis data dalam penelitian ini dilakukan secara kuantitatif dengan yang menggunakan alat statistik regresi linier berganda (multiple linier regresion) dengan bantuan software statistik SPSS 16. Hal ini untuk mengetahui hubungan antara variabel independen dengan variebel dependen, dimana jumlah variabel independen yang digunakan adalah 2 (lebih dari 1). Persamaan regresi dalam penelitian ini dapat dirumuskan sebagai berikut:

Keterangan:

$$
Y=\alpha+\beta 1 X 1+\beta 2 X 2+\beta 3 X 3+\varepsilon
$$

$\mathrm{Y}=$ Kepatuhan Wajib Pajak Orang Pribadi

$\boldsymbol{\alpha}=$ Konstanta

$\mathrm{X}_{1} \quad=$ Penerapan Sistem Administrasi Perpajakan Modern

$\mathrm{X}_{2} \quad=$ Kualitas Pemeriksaan Pajak 


\section{Uji Statistik Deskriptif}

Statistik digunakan untuk menggambarkan dan meringkas hal-hal penting dari data. Hal-hal penting tersebut antara lain berupa nilai maksimum dan minimum, standar deviasi, frekuensi, penyebaran dan pemusatan data. Statistik deskriptif berusaha menggambarkan berbagai karakteristik data seperti rata-rata (mean), standar deviasi dan sebagainya.

\section{Uji Kualitas Data}

Komitmen untuk mengukur dan menguji sebuah kuesioner atau hipotesis sangat bergantung pada kualitas data yang digunakan dalam pengujian tersebut. Data penelitian tidak akan berguna dengan baik jika instrumen yang digunakan untuk mengumpulkan data tidak memiliki tingkat keandalan (reliability) dan tingkat keabsahan (Validity) yang tinggi. Oleh karena itu, terlebih dahulu kuesioner harus diuji keandalan dan keabsahannya.

\section{Uji Validitas}

Uji validitas diperlukan agar mengukur sah/valid dan tidaknya sebuah kuesioner sebagai suatu instrumen penelitian. Kuesioner dikatakan valid jika pertanyaan dalam kuesioner mampu mengungkapkan sesuatu yang akan diukur oleh kuesioner tersebut (Sunyoto, 2011) dalam (Tiro, 2014). Pengujian ini menggunakan metode Pearson Corelation, data dikatakan valid apabila korelasi antara skor masing-masing butir pertanyaan dengan total skor setiap konstruknya signifikan pada level 0,05 (Ghozali Imam, 2011) dalam (Lestari, 2014)

\section{Uji Reliabilitas}

Reliabilitas adalah alat untuk mengukur suatu kuesioner yang merupakan indikator dari varibel yang diteliti (Sunyoto, 2011) dalam (Tiro, 2014). Pertanyaan dalam kuesioner dikatakan handal jika jawaban seseorang terhadap pertanyaan adalah konsisten. Uji reliabilitas pengukuran dalam penelitian ini dilakukan dengan menggunakan Cronbach`s alpha. Untuk menguji reliabilitas insreument, semakin dekat kofisien keandalan dengan 1,0 maka akan semakiin baik. Nilai reabilitas dinyatakan realiable jika mempunyai nilai Cronbach's Alpha dari masing-masing instruement yang dikatakan reliabel jika $\left(\mathrm{r}_{\mathrm{i}}\right)>0,60$ (Ghozali Imam, 2011) dalam (Lestari, 2014).

\section{Uji Asumsi Klasik}

Model regresi wajib memenuhi beberapa asumsi yang disebut asumsi klasik. Uji asumsi klasik dimaksudkan untuk menghindari perolehan yang bias. Adapun uji asumsi klasik yang digunakan dalam penelitian ini yaitu sebagai berikut:

\section{$\underline{\text { Uji Normalitas }}$}

Uji asumsi ini akan menguji data variabel bebas (x) dan variabel terikat (y) pada persamaan regresi yang dihasilkan, apakah berdistribusi normal atau berdistribusi tidak normal (Sunyoto, 2011) dalam (Tiro, 2014). Uji ini bertujuan menguji apakah ada variabel pengganggu atau variabel residual dalam model regresi.

Menurut (Ghozali Imam, 2011) dalam (Lestari, 2014) uji normalitas merupakan pengujian asumsi residual yang berdistribusi normal atau tidak. Model regresi yang baik adalah dimana model yang memiliki distribusi normal atau mendekati normal. Uji normalitas akan terpenuhi apabila sampel yang digunakan lebih dari 30, untuk mengetahui normalitas distribusi data dapat dilakukan dengan menggunakan analisis statistik, yaitu Kolmogrov-Smirnov test dengan kriteria pengujian $\alpha 0,05$ sebagai berikut:
a. Jika sig $\geq \alpha$ berarti data sampel yang diambil terdistribusi normal
b. Jika sig $\leq \alpha$ berarti data sampel yang diambil tidak terdistribusi normal

\section{$\underline{\text { Uji Multikolinieritas }}$}

Uji asumsi klasik ini digunakan untuk analisis regresi berganda yang terdiri dari minimal dua variabel bebas, dimana asumsi ini menyatakan bahwa antara variabel independen tidak terdapat gejala korelasi. Menurut (Ghozali Imam, 2011) dalam (Lestari, 2014) pengujian Multikolinieritasakan menggunakan Variance Inflationfactor (VIF) dengan kriteria yaitu: 
a. Jika nilai tolerance $<0.10$ dan VIF $>10$, maka terjadi multikolinearitas antara variabel independen.

b. Jika nilai tolerance $>0.10$ dan nilai $\mathrm{VIF}<10$, maka tidak akan terjadi multikolinearitas antara variabel independen.

Dapat disimpulkan bahwa, jika nilai Variance Inflation Factor (VIF) tidak lebih dari 10 dan nilai Tolerance tidak kurang dari 0,1 maka model dapat dikatakan terbebas dari multikolinieritas. Nilai tolerance (a) dapat dihitung dengan persamaan $(\mathrm{a}=1 / \mathrm{VIF})$, sementara nilai Variance Inflation Factor dapat dihitung dengan persamaan $(\mathrm{VIF}=1 / \mathrm{a})$. Variabel bebas mengalami multikolinieritas jika a hitung $<$ a dan VIF hitung < VIF (Sunyoto, 2011) dalam (Tiro, 2014)

\section{$\underline{\text { Uji Heterokedastisitas }}$}

Uji heteroskedastisitas bertujuan untuk menguji apakah sebuah model regresi terjadi ketidaksamaan varians dari residual atas satu pengamatan ke pengamatan lain tetap, maka disebut homoskedastisitas pada penelitian ini menggunakan Glejser Test. Pengujian ini membandingkan signifikas dari uji ini apabila hasilnya sig > 0,05 atau 5\%. Jika signifikan di atas 5\% maka disimpulkan model regresi tidak mengandung adanya heteroskedastisitas (Ghozali Imam, 2011) dalam (Lestari, 2014)

\subsection{Pengujian Hipotesis}

Hipotesis pada dasarnya adalah suatu proposi atau tanggapan yang sering digunakan sebagai dasar pembuatan keputusan atau solusi atas persoalan. Sebelum diuji, maka suatu data terlebih dahulu harus dikuantitafkan. Pengujian hipotesis statistik adalah prosedur yang memungkinkan keputusan dapat dibuat, yaitu keputusan untuk menolak atau menerima hipotesis dari data yang sedang diuji (Sunyoto, 2011) dan (Tiro, 2014). Dalam penelitian analisis yang akan digunakan yaitu analisis dengan regresi berganda. Analisis regresi berganda digunakan untuk mengetahui perngaruh variabel independen terhadap variabel dependen.

\section{Uji Parsial}

Menurut (Ghozali Imam, 2011) dalam uji stastistik t pada dasarnya menunjukkan seberapa jauh pengaruh satu variabel independen secara individual dalam menerangkan variabel dependen. Pengujian dilakukan dengan menggunakan significance level $0,05(\alpha=5 \%)$ dan $t$ tabel $=1,663$. Untuk mencari $t$ tabel dengan $\mathrm{df}=\mathrm{n}-\mathrm{k}(\mathrm{n}=$ jumlah responden, $\mathrm{k}=$ jumlah variabel (bebas dan terikat), tingkat signifikan 5\% $(\alpha=0,05)$, kemudian dapat melihat nilai $t$ tabel dengan menggunakan tabel statistik atau tabel $t$. Ditolak atau diterima sebuah hipotesis dapat dilihat dengan kriteria sebagai berikut:
a. Jika nilai signifikan $>0,05$ maka hipotesis ditolak (koefisien regresi tidak signifikan).
b. Jika nilai signifikan $\leq 0,05$ maka hipotesis diterima (koefisien regresi signifikan).
c. Jika $t$ hitung $>t$ tabel, maka hipotesis diterima.
d. Jika $t$ hitung $<t$ tabel, maka hipotesis ditolak.

\section{Uji Koefisien Determinasi}

Koefisien Determinasi $\left(\mathrm{R}^{2)}\right.$ digunakan untuk mengetahui seberapa besar variabel independen dapat menjelaskn variabel dependen. Nilai koefisien determnasi adalah antara nol dan satu. Nilai $\mathrm{R}^{2}$ yang berarti kemampuan variabel-variabel independen dalam menjelaskan varaiasi variabel dependen sangat terbatas. Nilai yang mendekati angka satu berarti variabel-variabel independen memberikan hampir semua informasi yang dibutuhkan untuk memprediksi variasi variabel dependen (Ghozali Imam, 2011).

\section{Hasil Dan Pembahasan}

\subsection{Gambaran Umum Responden}

Dalam penelitian ini yang menjadi objek penelitian adalah Wajib Pajak Orang Pribadi yang memiliki usaha (UMKM) di Kota Jayapura. Kuesioner dibagi secara online menggunakan google form melalui media sosial (Whatsapp). 
Tabel 1. Analisis Tingkat Pengisian Kuesioner

\begin{tabular}{lll}
\hline \multicolumn{1}{c}{ Keterangan } & Jumlah (orang) & Persentase(\%) \\
\hline Jumlah kuesioner yang disebarkan & 100 & $100 \%$ \\
Jumlah kuesioner yang tidak diisi & 14 & $14 \%$ \\
Jumlah kuesioner yang diisi & 86 & $86 \%$ \\
Total kuesioner yang diolah & 86 & $86 \%$ \\
\hline
\end{tabular}

Sumber: Olah Data Primer, 2020

\subsection{Statistik Deskriptif}

Statistik deskriptif mempunyai tujuan untuk memberikan gambaran variabel-variabel penelitian. Hasil analisis deskriptif dengan mengunakan program SPSS 16 dapat dilihat dari tabel 2 berikut:

Tabel 2. Statistik Deskriptif

\begin{tabular}{|c|c|c|c|c|c|}
\hline Variabel & $\mathrm{N}$ & Minimum & Maximum & Mean & Std. Deviation \\
\hline T.PSAPM & 86 & 4 & 20 & 15.17 & 3.431 \\
\hline T.KPP & 86 & 11 & 25 & 20.41 & 2.338 \\
\hline T.KM & 86 & 7 & 20 & 16.16 & 3.339 \\
\hline T.KWP & 86 & 11 & 25 & 20.02 & 3.399 \\
\hline Valid N (listwise) & 86 & & & & \\
\hline
\end{tabular}

Sumber: Data Primer diolah 2020

Variabel Penerapan Sistem Administrasi Perpajakan Modern mempunyai bobot jawaban antara lain nilai minimum sebesar 4 dan nilai maksimum 20 dengan nilai rata-rata 15.17 dan standar deviasi 3.431. Variabel Kualitas Pemeriksaan Pajak mempunyai bobot jawaban antara lain minimum sebesar 11 dan nilai maksimum 25 dengan nilai rata-rata 20.41 dan standar deviasi 2.338. Variabel Kesadaran Masyarakat mempunyai bobot antara lain nilai minimum sebesar 7 dan nilai maksimum 20 dengan nilai rata-rata 16.16 dan standar deviasi 3.339. Sedangkan untuk Variabel Kepatuhan Wajib Pajak dengan mempunyai nilai minimum sebesar 11 dan nilai maksimum 25 dengan nilai rata-rata 20,02 dan standar deviasi 3.399.

\subsection{Uji Kualitas Instrumen}

\section{Hasil Uji Validitas}

Tabel 3. Hasil Uji Validitas Penerapan Sistem Administrasi Perpajakan

\begin{tabular}{cccc}
\hline Item Pertanyaan & rhitung & Signifikan & Keterangan \\
\hline PSAPM 1 & 0,875 & 0,000 & Valid \\
PSAPM 2 & 0,916 & 0,000 & Valid \\
PSAPM 3 & 0,958 & 0,000 & Valid \\
PSAPM 4 & 0,953 & 0,000 & Valid \\
\hline
\end{tabular}

Sumber: Data Primer diolah, 2020

Berdasarkan tabel 3 di atas, hasil dari uji validitas variabel Penerapan Sistem Administrasi Perpajakan Modern memiliki nilai signifikansi dibawah 0,05. Hal tersebut bahwa seluruh pertanyaan mempunyai kriteria valid. 
Tabel 4. Hasil Uji Validitas Kualitas Pemeriksaan Pajak

\begin{tabular}{crrr}
\hline Item Pertanyaan & rhitung & Signifikan & Keterangan \\
\hline KPP 1 & 0,582 & 0,000 & Valid \\
KPP 2 & 0,534 & 0,000 & Valid \\
KPP 3 & 0,653 & 0,000 & Valid \\
KPP 4 & 0,861 & 0,000 & Valid \\
KPP 5 & 0,767 & 0,000 & Valid \\
\hline
\end{tabular}

Sumber: Data Primer diolah, 2020

Berdasarkan tabel 4 di atas, hasil dari uji validitas variabel Kualitas Pemeriksaan Pajak memiliki nilai signifikansi dibawah 0,05 . Hal tersebut bahwa seluruh pertanyaan mempunyai kriteria valid.

Tabel 5. Hasil Uji Validitas Kesadaran Masyarakat

\begin{tabular}{cccc}
\hline Item Pertanyaan & $\mathrm{r}$ hitung & Singnifikan & Keterangan \\
\hline KM1 & 0,519 & 0,000 & Valid \\
KM2 & 0,864 & 0,000 & Valid \\
KM3 & 0,911 & 0,000 & Valid \\
KM4 & 0,846 & 0,000 & Valid \\
\hline
\end{tabular}

Sumber: Data Primer diolah, 2020

Berdasarkan tabel 5 di atas, hasil dari uji validitas variabel Kesadaran Masyarakat memiliki nilai signifikansi dibawah 0,05 . Hal tersebut bahwa seluruh pertanyaan mempunyai kriteria valid.

Tabel 6. Hasil Uji Validitas Kepatuhan Wajib Pajak

\begin{tabular}{cccc}
\hline Item Pertanyaan & $\mathrm{r}_{\text {hitung }}$ & Singnifikan & Keterangan \\
\hline KWP1 & 0,717 & 0,000 & Valid \\
KWP2 & 0,586 & 0,000 & Valid \\
KWP3 & 0,913 & 0,000 & Valid \\
KWP4 & 0,842 & 0,000 & Valid \\
KWP5 & 0,888 & 0,000 & Valid \\
\hline
\end{tabular}

Sumber: Data Primer diolah, 2020

Berdasarkan tabel 6 di atas, hasil dari uji validitas variabel Kepatuhan Wajib Pajak memiliki nilai signifikansi dibawah 0,05. Hal tersebut bahwa seluruh pertanyaan mempunyai kriteria valid.

\section{Hasil Uji Reliabilitas}

Tabel 7. Hasil Uji Validitas Kepatuhan Wajib Pajak

\begin{tabular}{cccc}
\hline Variabel & Conbrach's Alpha & Standar Penerimaan & Keterangan \\
\hline X1 & 0,943 & $\geq 0,60$ & Reliabel \\
X2 & 0,708 & $\geq 0,60$ & Reliabel \\
X3 & 0,807 & $\geq 0,60$ & Reliabel \\
Y & 0,881 & $\geq 0,60$ & Reliabel \\
\hline
\end{tabular}

Sumber: Data Primer diolah, 2020 
Berdasarkan tabel 7 di atas, menunjukkan nilai cronbach's alpha atas variable Penerapan Sistem Administrasi Perpajakan Modern (X1) sebesar 0,943, Kualitas Pemeriksaan Pajak (X2) sebesar 0,708, Kesadaran Masyarakat (X3) sebesar 0,807, dan Kepatuhan Wajib Pajak Orang Pribadi (Y) sebesar 0,881. Dengan demikian, dapat disimpulkan bahwa pernyataan dalam kuesioner ini reliabel karena mempunyai nilai cronbach's alpha lebih besar dari 0,60. Hal ini menunjukkan bahwa setiap item pernyatan yang digunakan akan mampu memperoleh data yang konsisten yang berarti bila pernyataan itu diajukan kembali akan diperoleh jawaban yang relatif sama dengan jawaban sebelumnya.

\subsection{Uji Asumsi Klasik}

\section{$\underline{\text { Uji Normalitas }}$}

Dari hasil pengujian yang dilakukan dalam penelitian ini, menunjukkan bahwa data yang digunakan terdistribusi secara normal dapat dilihat pada tabel 8:

Tabel. 8 One-Sample Kolmogorov-Smirnov Test

\begin{tabular}{llr}
\hline \multicolumn{1}{c}{ Parameter } & & Unstandardized Residual \\
\hline $\mathrm{N}$ & & 86 \\
Normal Parameters ${ }^{\mathrm{a}}$ & Mean & .0000000 \\
& Std. Deviation & 1.30037020 \\
Most Extreme Differences & Absolute & .118 \\
& Positive & .118 \\
Kolmogorov-Smirnov Z & Negative & -.054 \\
Asymp. Sig. (2-tailed) & & 1.091 \\
a. Test distribution is Normal. & & .185 \\
\hline
\end{tabular}

Sumber: Data Primer diolah, 2020

Untuk lebih menyakinkan dilakukan pengujian normalitas menggunakan metode analisis grafik dengan mengamati grafik-grafik p-plot. Hasil uji normalias residual dapat dilihat pada gambar dibawah ini:

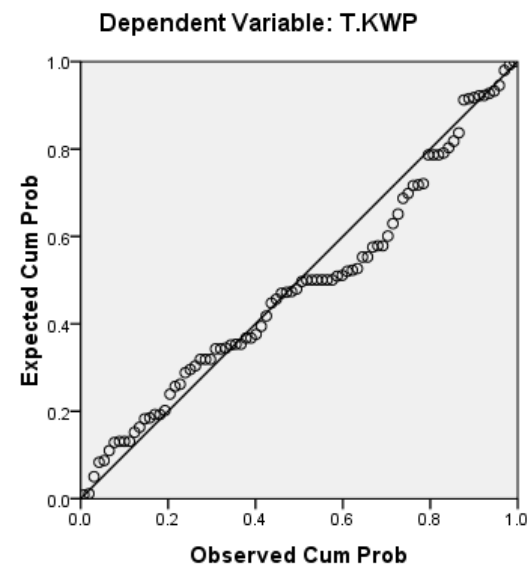

Gambar 1. Normal P - P of Regresion Standardized Residual

Dependent Variabel: Kepatuhan Wajib Pajak

Sumber: Data primer diolah, 2020 
Jika dilihat Berdasarkan pada gambar 1 di atas, dapat dilihat bahwa penyebaran data (titik) mengikuti arah garis diagonal. Maka data dikatakan terdistribusi normal karena penyebarannya disekitar garis diagonal dan mengikuti arah garis diagonal.

Uji Multikolinearitas

Tabel 9. Hasil Uji Multikolinearitas

\begin{tabular}{llcl}
\hline \multicolumn{1}{r}{ Model } & Tolerance & Collinearity Statistics & VIF \\
\hline 1 & (Constant) & & \\
& T.PSAPM & .576 & 1.737 \\
T.KPP & .597 & 1.676 \\
T.KM & .949 & 1.054 \\
\hline
\end{tabular}

Sumber: Data Primer diolah, 2020

Berdasarkan tabel 9 di atas terlihat bahwa nilai tolerance mendekati angka 1 dan nilai inflation factor (VIF) di sekitar angka 1 untuk setiap variabel, dapat disimpulkan bahwa variabel indenpenden menunjukan terjadinya multikolinearitas dengan ditunjukannya nilai tolerance value $<0,10$ dan VIF $>10$ yang berarti adanya korelasi diantara variabel indenpeden tersebut. Dengan demikian, hasil analisis menunjukkan tidak adanya masalah multikolinieritas dalam model regresi.

\section{Uji Heterokedastisitas}

Adapun hasil uji heterokedastisitas dalam penelitian ini disajikan pada tabel berikut ini:

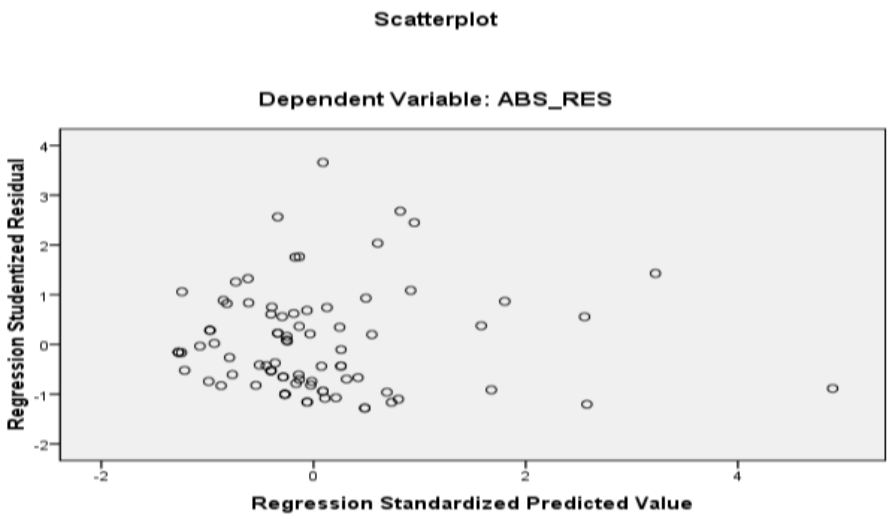

Gambar 2. Uji Heterokedastisitas (Sumber: Data Primer diolah, 2020)

Berdasarkan pada Gambar 2 scatter plot di atas menunjukkan titik-titik menyebar secara acak di atas dan di bawah nilai 0 pada sumbu Y. Berdasarkan hasil tersebut dapat disimpulkan bahwa tidak terjadi heterokedastisitas dalam model regresi yang digunakan, dengan demikian asumsi non heterokedastisitas terpenuhi. 


\subsection{Analisis Data}

Koefisien Determinasi (R2)

Tabel 10. Hasil Uji Koefisien Determinasi (R2)

\begin{tabular}{ccccc}
\hline Model & $\mathrm{R}$ & R Square & Adjusted R Square & Std. Error of the Estimate \\
\hline 1 & $.924^{\mathrm{a}}$ & .854 & .848 & 1.324 \\
\hline
\end{tabular}

Sumber: Data Primer diolah, 2020

Tabel 10 menunjukkan nilai koefisien korelasi ganda sebesar 0,924, berarti terdapat hubungan positif yang moderat antara Penerapan Sistem Administrasi Perpajakan Modern, Kuliatas Pemeriksaan Pajak, Kesadaran Masyarakat terhadap Kepatuhan Wajib Pajak Orang Pribadi di Kota Jayapura. Selanjutnya, nilai koefisien determinasi (Adjusted R Square) menunjukan bahwa besarnya kontribusi variabel independen terhadap variabel dependen adalah sebesar 0,848 atau 84,8\% sedangkan sisanya $15,2 \%$ dijelaskan oleh faktor-faktor lain yang tidak dijelaskan dalam penelitian ini.

Uji Statistik t (t-test)

Tabel 11. Hasil Uji t

\begin{tabular}{|c|c|c|c|c|c|c|}
\hline & \multirow[t]{2}{*}{ Model } & \multicolumn{2}{|c|}{ Unstandardized Coefficients } & \multirow{2}{*}{$\begin{array}{c}\text { Standardized } \\
\text { Coefficients }\end{array}$} & \multirow[t]{2}{*}{$\mathrm{t}$} & \multirow[t]{2}{*}{ Sig } \\
\hline & & B & Std. Error & & & \\
\hline \multirow{4}{*}{1} & (Constant) & 1.586 & 1.408 & & 1.126 & .263 \\
\hline & T.PSAPM & .768 & .055 & . 776 & 13.926 & .000 \\
\hline & T.KPP & .263 & .080 & .181 & 3.307 & .001 \\
\hline & T.KM & .087 & .044 & .086 & 1.979 & .051 \\
\hline
\end{tabular}

Sumber: Olah Data Primer, 2020

Berdasarkan tabel 11 maka diperoleh persamaan regresi sebagai berikut:

$\mathrm{Y}=1.586+0,768 \mathrm{X} 1+0,263 \mathrm{X} 2+0,087 \mathrm{X} 3+€$

Dimana:

$\mathrm{Y} \quad=$ Kepatuhan Wajib Pajak Orang Pribadi

$\mathrm{X} 1=$ Penerapan Sistem Administrasi Perpajakan Modern

$\mathrm{X} 2=$ Kuliatas Pemeriksaan Pajak

$\mathrm{X} 3=$ Kesadaran Masyarakat

$€ \quad=$ Eror

\subsection{Uji Hipotesis dan Pembahasan}

Pengaruh Penerapan Sistem Administrasi Perpajakan Modern terhadap Kepatuhan Wajib Pajak Orang Pribadi

Penerapan Sistem Administrasi Perpajakan Modern dapat mempengaruhi Kepatuhan Wajib Pajak Orang Pribadi. Hal ini dapat dilihat dari nilai probabilitas Penerapan Sistem Administrasi Perpajakan Modern yang lebih kecil dari alpha dalam penelitian ini (5\%), yaitu $0,000 \leq 0,05$. Sehingga dapat disimpulkan bahwa hipotesis pertama (H1): Penerapan Sistem Administrasi Perpajakan Modern Berpengaruh Terhadap Kepatuhan Wajib Pajak Orang Pribadi, diterima.

\section{Pengaruh Kualitas Pemeriksaan Pajak terhadap Kepatuhan Wajib Pajak Orang Pribadi}

Kuliatas Pemeriksaan Pajak dapat mempengaruhi Kepatuhan Wajib Pajak Orang Pribadi Yang Memiliki UMKM di Kota Jayapura. Hal ini dapat dilihat dari nilai probabilitas Kuliatas Pemeriksaan 
Pajak yang lebih kecil dari alpha dalam penelitian ini (5\%), yaitu $0,001 \leq 0,05$. Sehingga dapat disimpulkan bahwa hipotesis kedua (H2): Kuliatas Pemeriksaan Pajak Berpengaruh Terhadap Kepatuhan Wajib Pajak Orang Pribadi Yang Memiliki UMKM di Kota Jayapura, diterima.

\section{Pengaruh Kesadaran Masyarakat terhadap Kepatuhan Wajib Pajak Orang Pribadi}

Kesadaran Masyarakat tidak dapat mempengaruhi Kepatuhan Wajib Pajak Orang Pribadi. Hal ini dapat dilihat dari nilai probabilitas Kesadaran Masyarakat yang lebih besar dari alpha dalam penelitian ini (5\%), yaitu 0,051 >0,05. Sehingga dapat disimpulkan bahwa hipotesis ketiga (H3): Kesadaran Masyarakat Tidak Berpengaruh Terhadap Kepatuhan Wajib Pajak Orang Pribadi, ditolak.

\section{Penutup}

\subsection{Kesimpulan}

Penelitian ini bertujuan untuk meneliti Pengaruh Penerapan Sistem Administrasi Perpajakan Modern, Kualitas Pemeriksaan Pajak, Kesadaran Masyarakat, dan Kepatuhan WPOP Yang Memiliki UMKM di Kota Jayapura. Dalam penelitian ini terdapat tiga hipotesis yang diuji. Variabel dependen yang digunakan adalah Kepatuhan Wajib Pajak Orang Pribadi, Variabel Independen yang digunakan adalah Penerapan Sistem Administrasi Perpajakan Modern, Kualitas Pemeriksaan Pajak, Kesadaran Masyarakat. Responden dalam penelitian ini berjumlah 100 Wajib Pajak Orang Pribadi yang memiliki UMKM di Kota Jayapura. Berdasarkan hasil analisis dan pengujian hipotesis dapat dibuat kesimpulan sebagai berikut:

1) Hasil uji menunjukkan bahwa Penerapan Sistem Administrasi Perpajakan Modern Berpengaruh Terhadap Kepatuhan Wajib Pajak Orang Pribadi Yang Memiliki UMKM di Kota Jayapura. Hal ini menunjukan bahwa semakin Baik Penerapan Sistem Administrasi Perpajakan Modern maka semakin baik Kepatuhan Wajib Pajak Orang Pribadi Yang Memiliki UMKM di Kota Jayapura.

2) Hasil uji menunjukkan bahwa Kualitas Pemeriksaan Pajak Berpengaruh Terhadap Kepatuhan Wajib Pajak Orang Pribadi Yang Memiliki UMKM di Kota Jayapura. Hal ini menunjukan bahwa semakin baik Kualitas Pemeriksaan Pajak maka semakin baik Kepatuhan Wajib Pajak Orang Pribadi Yang Memiliki UMKM di Kota Jayapura.

3) Hasil uji menunjukkan bahwa Kesadaran Masyarakat Tidak Berpengaruh Terhadap Kepatuhan Wajib Pajak Orang Pribadi Yang Memiliki UMKM di Kota Jayapura. Hal ini menunjukan bahwa kurangnya pemahaman, pengetahuan dan peraturan perpajakan sehingga membuat masyarakat tidak patuh dalam membayar pajak.

\subsection{Keterbatasan}

Adapun keterbatasan dalam penelitian ini adalah sebagai berikut:

1) Keterbatasan penelitian ini dimana peneliti hanya menggunakan metode kuesioner online melalui google form, tanpa melakukan interview langsung kepada responden.

2) Penelitian ini juga hanya dilakukan pada Wajib Pajak Orang Pribadi Yang Memiliki UMKM di Kota Jayapura sehingga hasil kurang dapat digeneralisasi secara luas.

3) Peneliti hanya menggunakan variabel Penerapan Sistem Administrasi Perpajakan Modern, Kualitas Pemeriksaan Pajak dan Kesadaran Masyarakat untuk mengukur Kepatuhan Wajib Pajak Orang Pribadi.

\subsection{Saran}

Dari kesimpulan penelitian yang telah diperoleh, adapun saran dalam penelitian ini adalah sebagai berikut:

1) Penelitian selanjutnya diharapkan untuk penampilkan data terkait dengan informasi responden berupa Omset, Aset dan Laba Diterima. 
2) Penelitian selanjutnya diharapkan dapat mengunakan responden bukan hanya WPOP yang memiliki usaha saja tetapi kalau bisa semua WPOP yang berada di Kota Jayapura, sehingga hasil penelitian dapat digeneralisasi secara luas.

3) Penelitian selanjutnya diharapkan dapat menambahkan jumlah variabel yang mempengaruhi Kepatuhan Wajib Pajak Orang Pribadi Yang Memiliki UMKM di Kota Jayapura seperti variabel yang memuat informasi responden yaitu omset, aset dan laba diterima

\section{Daftar Pustaka}

Cermati.com. (2019). Jenis-Jenis Pemeriksaan Pajak yang Perlu Diketahui Wajib Pajak. Www.Cermati.Com.

Chaizi, N. (2010). Sedangkan menurut Chaizi Nasucha Dalam Siti Kurnia. www.coursehero.com: 139.\%0Ahttps://www.coursehero.com/file/pmork4/Sedangkan-menurut-ChaiziNasucha-dalamSiti-Kurnia-Rahayu-2010139-Kepatuhan/

Dewi, M. R. (2011). Persepsi Wajib Pajak Atas Pengenaan Pajak Penghasilan: Anteseden dan Konsekuensinya (Kajian Empiris Pada Wajib Pajak Orang Pribadi Yang Memiliki Usaha di Kota Kudus). Universitas Diponegoro Semarang.

Ghozali Imam. (2011). Aplikasi Analisis Multivariate dengan Program SPSS. Undip.

Ii, D. (2013). www.jdih.kemenkeu.go.id.

Kristianto Galuwo. (2020). Aplikasi e-Filing bantu tingkatkan kepatuhan wajib pajak.

Lestari, T. (2014). Pengaruh Keadilan Organisasi Dan Sistem Pengendalian Intern Pemerintah (SPIP) Terhadap Kecurangan (Fraud) Pada SKPD Kabupaten Kaur. Skripsi.

Lumbantoruan, P. (2014). Pengaruh Penerapan Sistem Administrasi Perpajakan Modern, Kualitas Pemeriksaan Pajak Dan Kesadaran Masyarakat Terhadap Kepatuhan Wajib Pajak (Survei Pada WPOP Di KPP Pratama Bandung Cibeunying). Society, 1-16.

Mardiasmo. (2009). Pemeriksaan Pajak. Https://Tanyapajak1.Wordpress.Com/.

Muliari dan Setiawan. (2010). Membangun Kesadaran Dan Kepedulian Sukarela Wajib Pajak. Www.Pajak.Go.Id.

Rahayu, S. K. (2009). Definisi Sistem Administrasi Perpajakan Modern Menurut. Journal of Chemical Information and Modeling, 53(9), 1689-1699. https://doi.org/10.1017/CBO9781107415324.004

Rahayu, S. K. (2010). Kepatuhan Wajib Pajak. Www.Hestanto.Web.Id.

Sugiyono, P. D. (2014). Metode Penelitian Bisnis. ALFABETA, CV.

Sunyoto, D. (2011). Analisis Regresi dan Uji Hipotesis. caps.

Suparman, R. A. (2018). Prinsip Self Assessment Menurut Ketentuan Umum Perpajakan Di Indonesia. https://aguspajak.com/.\%0Ahttps://aguspajak.com/2018/01/23/prinsip-self-assessmentmenurutketentuan-umum-perpajakan-di-indonesia/

Surjono, W. (2015). Pengaruh Modernisasi Administrasi Perpajakan Terhadap Kepuasan Wajib Pajak pada Kantor Pelayanan Pajak Pratama Bandung Bojonagara. Jurnal ASET (Akunansi Riset), 7(2), 13.

Tiro, A. A. A. (2014). Pengaruh Pengendalian Internal dan Kompensasi Terhadap Kecenderungan Kecurangan (Fraud) Pada Pemerintah Kota Palopo. Skripsi.

Valenty, Yola Andesta, \& H. K. (2019). Determinan Kepatuhan Pajak Perspektif Theory of Planned Behavior dan Teori Institusional. 